\title{
Microbial Enzymatic Degumming of Crude Soybean Oil (Lecitase Novo Form Aspergillus Orizae)
}

\author{
Prabhaharan. $\mathbf{M}^{1}$, Rakshit. S. $\mathrm{K}^{2}$ \\ ${ }^{I}$ Department of Agric.Engineering, Faculty of Agriculture, University of Jaffna \\ ${ }^{2}$ Post-Harvest \& Food Engineering division, School of SERD, AIT, Thailand
}

*Corresponding Author: Kubkomawa, H. I, Department of Animal Production and Health, Federal Polytechnic, Pmb 35, Mubi, Adamawa State, Nigeria

\begin{abstract}
Quality of edible oil mainly depended on properties such as phosphatide level (Gum), acid value and peroxide value. Higher free fatty acid (acid value) and peroxide value generally reduce the edible oil quality. Removal of free fatty acid from crude edible oils can be done by chemical neutralization combined with physical refining like vacuum distillation. The latter method requires that the phosphatide (Gum) content less than 10 ppm. Here target level of gum removal (Degumming) was attempted by using microbial enzyme (Lecitase Novo) secreted by Aspergillus orizae combine with water degumming under optimum condition with mixing. The enzymatic degumming process was employed to reduce the level of phosphatide $(P)$ to 10 ppm at six (06) hours of duration with mixing. A chemical degumming process was attempted with citric acid and sodium hydroxide, exhibiting a speeded in reduction of the gum level to less than 10ppm in 2 to 3 hours of mixing, where the constant parameters crude oil one liter, $1.5 \%$ of water, $1.5 \%$ Buffer $10.05 \%$ citric acid 50\% solution and $4 \mathrm{M} \mathrm{NaOH}$ solution with neutral $\mathrm{pH}$ ) mixing speed $1000 \mathrm{rpm}$ with peddle type stirrer, viscosity of $0.0322 \mathrm{~kg} / \mathrm{m} . \mathrm{s}$, density of $930 \mathrm{~kg} / \mathrm{m} 3$, with constant temperature at $400 \mathrm{C}$ in water bath. Quality of edible oil mainly depended on properties such as phosphatide level, acid value and peroxide value. Crude soybean oil contains phosphatide 700 - 750 ppm, acid value $1.82 \%$ and peroxide value 5 meq / $\mathrm{kg}$. After degumming process chemical and enzymatic degummed oils expressed that the value of phosphatide less than $10 \mathrm{ppm}$, acid value $4.55 \pm 0.46$ and $3.64 \pm 0.23$ peroxide value $10.5 \pm 0.5$ and $12.5 \pm 0.7$ respectively. The microbial phospholipase enzymes are an economically attractive in edible oil processing which exhibits some unique features while compared to chemical method.
\end{abstract}

Keywords: Soybean-oil, Enzymatic-Degumming, microbial phospholipase (Lecitase Novo).

\section{INTRODUCTION}

Soybean oil can also be processed so as to remove undesirable components such as phosphatides, trace metals and soaps. The oil extracted is highly unsaturated and temperature stable and remains in liquid oil form. Furthermore, there are several advantages of extracting oil from soybeans, as compared to other sources.

There are two types of phospholipids present in vegetable oils namely the hydratable and nonhydratable. Simple water degumming will not remove non-hydratable gums. High phosphatide containing oil like soybean oil (700ppm) water degumming alone is not satisfactorily to reduce the phosphatide content below 10ppm. Therefore enzymatic process is used together with water degumming. Degumming is an important step in oil refining process and removes phosphatide (gum) along with some other unwanted minor compounds without destroying the beneficial ones.

Gums tend to produce high refining losses, foaming, settling and discoloration of oil in processing and storage (P. Eickhoff, 2000). Degumming achieve this level and required to remove the non-hydratable phospholipids. The microbial enzymatic degumming is cost-efficient compared to chemical refining and other physical refining processes. Activity of Lecitase Novo is standardized in 4000 Lecitase Novo Units per g (4000 LENU/g).

The unit is defined relative to a Lecitase Novo standard. One unit is equivalent to the amount of enzyme producing $1 \mu$ mole of free fatty acid per minute under standard conditions using 1-(S- 
decanoyl)-2-decanoyl-1-thio-sn-glycero-3-phosphocholine (Novo Nordisk, 2000). Physical refining how ever requires phosphatide content to be less than $10 \mathrm{ppm}$ as they affect the vacuum distillation process at higher level. Enzymatic degumming achieve this level are required to remove the nonhydratable phospholipid, (Dahlke et al., 1995).

\section{OBJECTIVES OF THIS STUDY}

To quantify the refined-oil quality during the degumming processing of crude soybean oil.

\section{Materials AND MethodS}

\subsection{Enzymatic Degumming of Crude Soybean Oil}

Degumming process generally removes the major portion of phospholipids and some other sticky compounds. Although a number of parameters are involved during the water degumming process. . Degumming methods in the above experiments was further compared with chemical degumming in which a citric acid and $\mathrm{NaOH}$ mixture was used to remove gum simultaneously to an accelerated rate, (G.R. List. et al., 1993).

In Enzymatic degumming process water and enzyme (Lecitase Novo) are used in the removal of hydratable and non-hydratable gum was investigated in lab scale mixing reactor. $0.1 \mathrm{M}$ citrate buffers, at $\mathrm{pH} 4.5$ were mixed with the enzyme to maintain an acidic condition, which is optimum for the action of Lecitase Novo. Degumming process of crude oil as described in flow chart 1.

In this studies water and enzymatic degumming was performed separately in which $1.5 \%$ of water was added initially (an amount sufficient for the removal of hydratable gum at a considerable amount under the optimized conditions during the water degumming experiment) followed by the addition of $1.5 \%$ of water containing buffer and enzyme as described in flow chart 2, (Dahlke, K and H. Buchold, (1995).

\subsection{Lab Scale Mixing Reactor}

$500 \mathrm{ml}$ of crude oil or degummed was taken into the reactor, which was kept at about the temperature needed for the specific enzymatic reaction $\left(40^{\circ} \mathrm{C}\right)$. The lab mixing head was turned on that the oil starts to circulate from the reactor. The system is allowed to equilibrate for about 30 minutes, during which period the temperature is make it constant. The pre-treatment period $(\mathrm{t}=0)$ with addition of $1.5 \%(\mathrm{v} / \mathrm{v})$ water was added Just after this enzyme solution with buffer $1.5 \%(\mathrm{v} / \mathrm{v})$ were added to the system, at ( $\mathrm{t}=2 \mathrm{hr}) 2 \mathrm{ml}$ samples are drawn for phosphorus analysis and continue every two hours up to 6 hours. (www.ag.uiuc.edu/archives)

\section{Degummed Soybean OIL Properties}

\subsection{Analysis of Phosphorous}

Phospholipids become salts of phospholipids by combination of $\mathrm{MgNO}_{3}$. The rise in temperature $\left(250^{\circ} \mathrm{C}\right)$ brought about the carbonization of the oil. After one hour at this temperature oil becomes solid and then put in muffle furnace at $800^{\circ} \mathrm{C}$ for 3 hours.

Here all organic compounds are oxidized and escaped in the form of gas, inorganic compounds including phosphorus are remaining in the form of white ash. Ash is dissolved by HCL to get ionic form. Then Ammonium molybdate is added. Phospho-molibdate is produced. Then hydroquinone is added. This reduces the phosphor-molybdate and gives blue color. Absorbance of solution is measured at $600 \mathrm{~nm}$. By using standard curve $\mathrm{P}$ content is to be determined as shown in the flow chart 3.

\subsection{Standard Curve}

To prepare the standard solution $0.4589 \mathrm{~g}$ of $\mathrm{KH}_{2} \mathrm{PO}_{4}$ are dissolved in distilled water and the volume was made up-to $100 \mathrm{ml}$. In this solution Phosphatide concentration is $1000 \mathrm{ppm}$. Each $10 \mathrm{ml}$ solution was taken and $5 \mathrm{ml}$ ammonium molybdate, $2 \mathrm{ml}$ sodium sulphite and $2 \mathrm{ml}$ hydroquinone were added to color reaction and absorption was measured at $600 \mathrm{~nm}$ by using spectrophotometer. Graph was plotted against Absorption vs. Concentration of original solution. Equation obtained was $\mathrm{Y}=0.0216 \mathrm{X}+$ 0.0076 (with an $R^{2}$ of 0.9998). 


\subsection{Calculation of P Content in Oil}

$5 \mathrm{ml}$ of sample (crude or degummed oil) was taken into crucible and put in muffle furnace, ash was obtained, and then dissolved in $5 \mathrm{ml} 6 \mathrm{~N} \mathrm{HCL}, 2.5 \mathrm{ml}$ distilled water was added, filtered into $50 \mathrm{ml}$ volumetric flask, made the volume to $50 \mathrm{ml}$ with distilled water. $10 \mathrm{ml}$ of above sample was taken for P analysis. (Racicot, L.D., and A.P. Handel, 1983). Flow chart1. Water degumming process

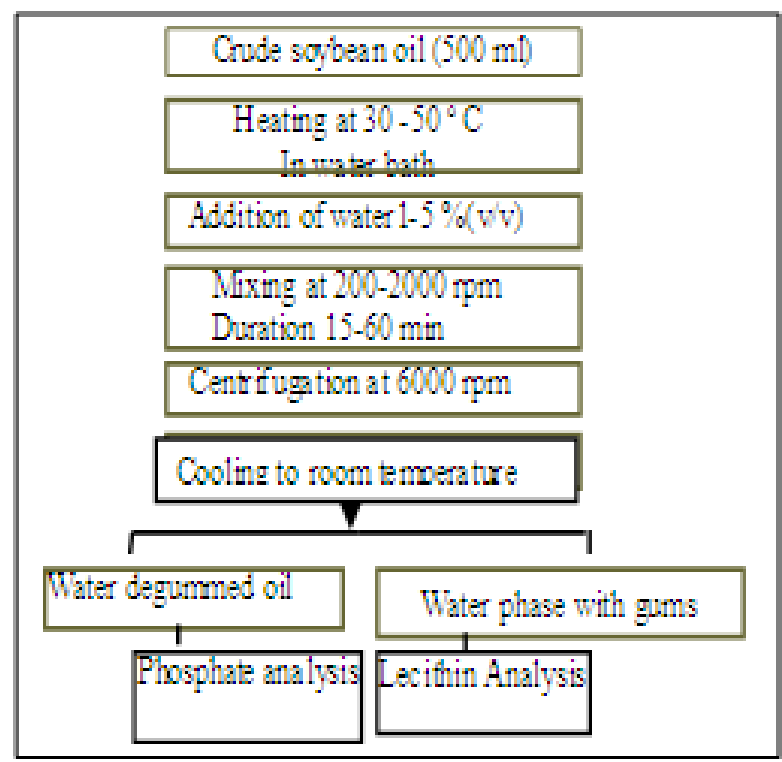

Flow Chart1. Water degumming process

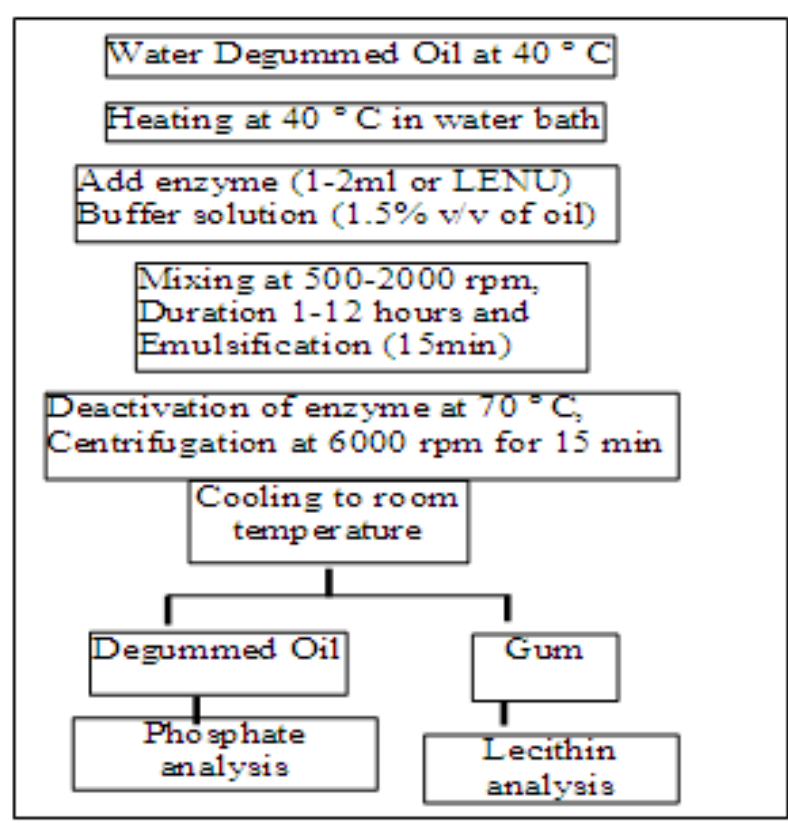

Flow Chart2. Enzymatic degumming process

\subsection{Viscosity Measurement of Soybean Oil}

Under the mixing requirement of enzymatic degumming of soybean oil, viscosity is an important parameter.

Viscosity measurement is calculated under the power rule of Newtonian fluid, which by the rotational Brook-field viscometer at various rotational speed (rpm) verses viscosity (centi Poise) at $40{ }^{\circ} \mathrm{C}$, (James Y. Oldshue, (1983)

\subsection{Density Measurement of Soybean Oil}

Weight of crude oil at particular temperature $\left(40^{\circ} \mathrm{C}\right)$ divided by same amount of water weight give the density of crude oil. 


\section{DEGUMMED SOYBEAN OIL QUALITY}

The quality analysis was performed following AOCS official methods (1996). The good oil quality depended on the free fatty acid and peroxide value. Free fatty acids are indices related to acid value. Free fatty acids are not desirable components of edible oil, particularly if used for frying, as they result in low smoke point (Synder, 1987).

\subsection{Free Fatty Acids (FFA)}

Oil quality largely depends on its content of free fatty acid. Higher free fatty (FFA) generally reduces oil quality and oxidative changes in oil results in rancid flavors and odors while in the production of FFA, that promotes foaming and thereby lowering the smoke point of heated oil.

Approximately 10-20 gm. of crude oil was weighed into $250 \mathrm{ml}$ Erlenmeyer flask, to which $50 \mathrm{ml}$ of $95 \%$ ethyl alcohol was added. The mixed sample was titrated with $0.1 \mathrm{~N}$ sodium hydroxide $(\mathrm{NaOH})$ solution, by using $2 \mathrm{ml}$ phenolphthalein as indicator. Percent FFA as oleic acid was calculated as the following:

$$
\text { FFA as oleic }=\frac{[\mathrm{ml} \text { of } \mathrm{NaOH} \times \mathrm{N} \times 28.2] \%}{[\text { Weight of sample }]}
$$

\subsection{Peroxide Value (PV)}

A measure of residual $\mathrm{H}_{2} \mathrm{O}_{2}$ from the degumming process of oil refining. Peroxide is sometimes used at low levels to lighten oil color. Crude oil weighing $5.00 \pm 0.05 \mathrm{gm}$ was put into $250 \mathrm{ml}$ erlenmeyer flask, and $50 \mathrm{ml}$ of 3:2 acetic acid / iso-octane solution was added. The sample was swirled to dissolve before adding $0.5 \mathrm{ml}$ of saturated potassium iodite (KI) solution.

The sample was allowed to stand for exactly 1 min (the solution was manually shaken during that time). Then $30 \mathrm{ml}$ of distilled water was immediately added. The sample was titrated with $0.01 \mathrm{~N}$ sodium thisulfate $\left(\mathrm{Na}_{2} \mathrm{~S}_{2} \mathrm{O}_{3} .5 \mathrm{H}_{2} \mathrm{O}\right)$ solution using $0.5 \mathrm{ml}$ of starch solution as indicator.

Peroxide Value (milleequivalents peroxide/ $10 \mathrm{C}-\frac{[(\mathrm{S}-\mathrm{B}) \times \mathrm{N} \times 1000]}{[\text { Weight of sample] }}$ gm sample)

Where: $-\mathrm{ml}$ of $\mathrm{Na}_{2} \mathrm{~S}_{2} \mathrm{O}_{3} .5 \mathrm{H}_{2} \mathrm{O}$ for blank tritration

$\mathrm{S}-\mathrm{ml}$ of $\mathrm{Na}_{2} \mathrm{~S}_{2} \mathrm{O}_{3} \cdot 5 \mathrm{H}_{2} \mathrm{O}$ for sample tritration

$\mathrm{N}$ - normality of $\mathrm{Na}_{2} \mathrm{~S}_{2} \mathrm{O}_{3} .5 \mathrm{H}_{2} \mathrm{O}$

\section{RESUlTS AND DISCUSSION}

\subsection{Description of Crude Soybean Oil}

Characteristics of soybean oil depends on the production process employed and may exhibit some differences. Before analyzing the degumming processes an attempt was made to investigate some of its properties and results were presented in Table 1

These parameters are comparable with products obtained from other sources.

Table1. Characteristics of crude soy bean oil

\begin{tabular}{|l|l|l|}
\hline No & Characteristics of oil & Value \\
\hline 1 & Phosphatide content $(\mathrm{ppm})$ & $700-750 \mathrm{ppm}$ \\
\hline 2 & Viscosity & $0.326 \mathrm{~Pa} \cdot \mathrm{s}^{\mathrm{n}}$ \\
\hline 3 & Density & $925 \mathrm{~kg} / \mathrm{m} 3$ \\
\hline 4 & Peroxide value & $5 \mathrm{meq} / \mathrm{kg}$ \\
\hline 5 & Free fatty acid & $1.82 \%$ \\
\hline
\end{tabular}

\subsection{Enzymatic Degumming of Crude Soybean Oil}

The investigation involves water and enzymatic degumming performed separately in which $1.5 \%$ of water was added initially (an amount sufficient for the removal of hydratable gum at a considerable 
amount under the optimized conditions during the water degumming experiment) followed by the addition of $1.5 \%$ of water containing the buffer $(0.1 \mathrm{M}$ citrate buffer) and enzyme (Lecitase Novo). The final amount of water was kept constant (3\%).

\subsection{Gum Removed by Water in the Degumming}

Water level increment from 1 to $3 \%$ at 500rpm decreased the phosphate concentration of the oil up to $157 \mathrm{ppm}$ in 30 minutes of mixing duration and remained almost constant afterwards. Among the temperatures tested $40^{\circ} \mathrm{C}$ slightly favored the water degumming process. As presented in Figure 4.

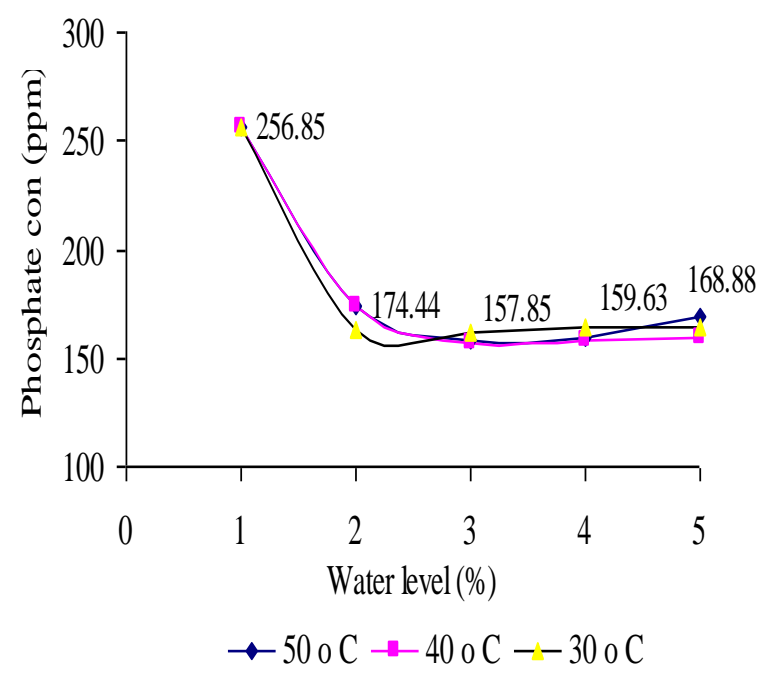

Fig4. Effect of water level and temperature on gum removal in water degumming of crude oil (500ml crude oil at $500 \mathrm{rpm}, 30 \mathrm{~min}$ )

\subsection{Gum Removed by Enzyme and Buffer in the Degumming Process}

The remaining hydratable and non-hydratable portions present in the degummed oil ranging from $160 \mathrm{ppm}$ to $180 \mathrm{ppm}$ were used as a starting material for the consecutive enzymatic degumming. $2.0 \mathrm{ml}$ enzyme removed the gum faster than the other levels and was found to reduce phosphate level to less than 10 ppm at 6 hours (Figure.5).

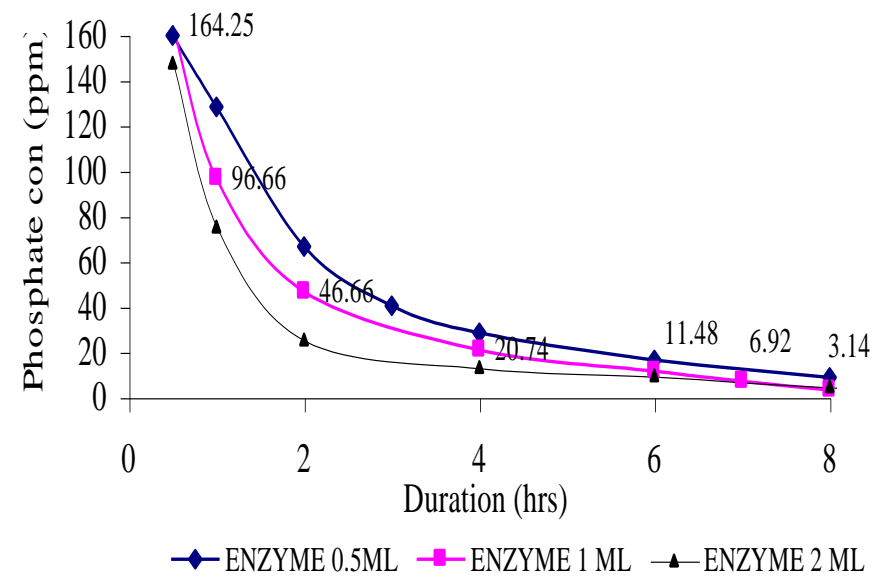

Fig5. Enzyme concentration in degumming of crude soybean oil.(500 ml crude oil, $1.5 \%$ water, $1.5 \%$ buffer, $1000 \mathrm{rpm}$ at 40 o $\mathrm{C}$ ).

\subsection{Chemical Degumming}

The above experiments were further compared with chemical degumming in which a citric acid and $\mathrm{NaOH}$ mixture was used to remove gum simultaneously to an accelerated rate it take 2 to 3 hours of mixing as shown in the figure 6. 


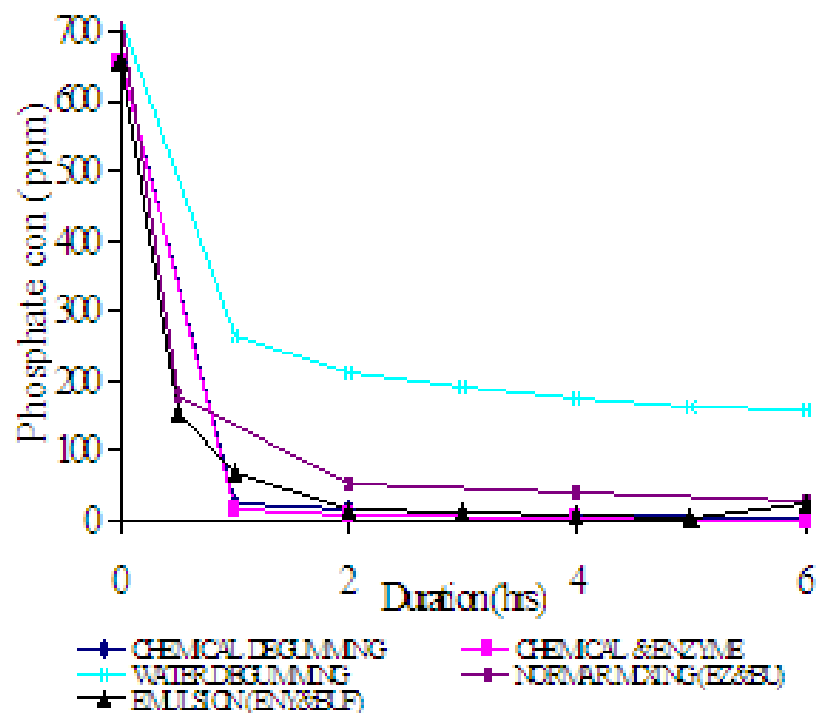

Fig6. Comparison of the different degumming methods. $(500 \mathrm{ml}$ crude oil, $1.5 \%$ buffer/chemical, $1.5 \%$ water 1 ml enzyme, $1000 \mathrm{rpm}$, tem 40oC)

\subsection{Comparison of Oil Quality}

\subsubsection{Free Fatty Acid (FFA)}

Free fatty acid value of oils from degumming processes was found to be different. The oil is considered as being safe, while FFA value should also be less.

FFA values of three different processing of oils were as follows.

\begin{tabular}{|l|l|}
\hline Type of degumming & FFA value: \\
\hline Crude oil & $1.82 \pm 0.15 \%$ \\
\hline Enzymatic degummed oil & $3.64 \pm 0.23 \%$ \\
\hline Chemical degummed oil & $4.55 \pm 0.46 \%$ \\
\hline
\end{tabular}

\subsubsection{Peroxide Value (PV)}

$P V$ values of the three different processing of oils were as follows

\begin{tabular}{|l|l|}
\hline Type of degumming & PV value: \\
\hline Crude oil & $05 \pm 0.35$ \\
\hline Enzymatic degummed oil & $10 \pm 0.35$ \\
\hline Chemical degummed oil & $12.5 \pm 0.70$ \\
\hline
\end{tabular}

Peroxide values of oil from degumming process were found to be different. PV value exceeding 15 is not acceptable and the oil is considered as being oxidized while FFA value should also be less than $5 \%$. The lower the FFA \& PV values the oil is more stable.

\section{CONCLUSIONS}

The following conclusions are drawn based on the results obtained from the various experiment.

Soybean oil used in this study exhibited a phosphatide content of 700-750ppm, a viscosity of 0.326 Pa. ${ }^{\mathrm{n}}$, a density of $925 \mathrm{Kg} / \mathrm{m}^{3}$, a peroxide value of $5 \mathrm{meq} / \mathrm{Kg}$, and a free fatty acid content of $1.82 \%$ which are comparable with products obtained from other sources.

The water degumming process $3 \%$ water level, $40^{\circ} \mathrm{C}$, and 30 minutes of mixing duration at $500 \mathrm{rpm}$ efficiently reduced the level of phosphatide and it reached 156ppm. Afterwards gum removal was constant. Water degumming alone is not satisfactorily to reduce the phosphatide content below $10 \mathrm{ppm}$.

In the enzymatic degumming process speeded the reduction of the gum level to less than 10ppm at 6 hours of mixing duration and degummed oil having acid value $3.64 \pm 0.23$ and peroxide value $10.5 \pm$ 0.5. Chemical degummed oils also gave the value of phosphatide less than $10 \mathrm{ppm}$ at 2 to 3 hours of mixing duration and degummed oil having acid value $4.55 \pm 0.46$ and peroxide $12.5 \pm 0.7$. 
Higher free fatty acid (Acid value) and peroxide value generally reduces the edible oil quality so that the microbial phospholipase enzymes are an economically attractive in edible oil processing which exhibits some unique features while compared to chemical method.

\section{REFERENCES}

[1] Carelle, A. A, M.I.V. and G.H. Crapiste, (1997) 'Quantitative determination of phospholipids in sun flower oil', JAOCS, 74:5511-514 Burkhardt, H.J., and G. Fuller, JAOCS 47:219 (1990).

[2] Dahlke, K and H. Buchold, (1995), 'first the enzymatic degumming process' Inform, 6:12, 1284-1291.

[3] Eickhoff, K.P., (2000) 'Degumming process in edible oil Industry' World Conference Proceedings on Edible Oils and Fat Processing - Basic Principles and Moderen Practices, Edited by S.C. Singhal, AOCS, Champaign, 2000.

[4] Erickson, D.R., Pryde, E.H., Brekke, O.L., Mounts, T.L., Falb, R.A. 1980. Handbook of Soy Oil Processing and Utilization. American Soybean Association and the American Oil Chemists Society. St. Louis, Missouri and Champaign, Illinois.

[5] List, G.R., J.M. Avellaneda and T.L. Mounts, Refining of soybean oil'JAOCS. 58: 892 (1993).

[6] James Y. Oldshue, (1983) Mixing Technology, Mixing Equipment Co. New York. Chemical Engineering. P. 43- 72, 192-216.

[7] Racicot, L.D., and A.P. Handel, (1983), 'Degumming of soybean oil: Quantitative analysis of Phospholipids in crude and degummed oil 1, 2 JA OCS 60: 6; 1098-1101.

[8] Re: soya oil degumming available online www.ag.uiuc.edu/archives/experts/ utilization/1998a/0015.html. [down loaded: Feb. 2, 2002]

[9] Novo Nordisk (2000), 'Lecitase novo enzyme product sheet' Available online h!ills:llwww.Mynovo zym...le2001-06954- n.html [down loaded: 11/10101]

Citation: Prabhaharan. M, Rakshit. S. K "Microbial Enzymatic Degumming of Crude Soybean Oil (Lecitase Novo Form Aspergillus Orizae)", International Journal of Research Studies in Agricultural Sciences (IJRSAS), vol. 3, no. 10, p. 7, 2017. http://dx.doi.org/ 10.20431/2454-6224.0310002

Copyright: (๑) 2017 Authors. This is an open-access article distributed under the terms of the Creative Commons Attribution License, which permits unrestricted use, distribution, and reproduction in any medium, provided the original author and source are credited. 